\title{
ANALISIS SPASIAL POTENSI HUTAN RAKYAT DI KABUPATEN BOGOR
}

\author{
Spatial Analysis of the Community Forest Potential in Bogor \\ Rahmat Safe'i ${ }^{1}$ dan M. Dedy P. Sukmara ${ }^{2}$ \\ ${ }^{1}$ Jurusan Kehutanan, Fakultas Pertanian, Universitas Lampung, Jl. Prof. Dr. Soemantri \\ Brojonegoro No. 1, Bandar Lampung 35145, Lampung, Indonesia. \\ ${ }^{2}$ Program Studi Konservasi Biodiversitas Tropika, Sekolah Pascasarjana, Institut Pertanian \\ Bogor, Jalan Raya Dramaga, Kampus IPB Dramaga, 16680, Bogor, Indoensia \\ Email: mat ane@yahoo.com
}

\begin{abstract}
In order to support the availability of wood raw material and increase the local economy in Bogor, one of the potential that can be developed is a community forest. Although the data and information about community forest areas not yet clearly. Potential data in community forest can get through a spatial approach using remote sensing and geographic information systems. Spatial analysis of the community forest potential was conducted to determine the distribution, extent and type of community forest cover in the district of Bogor. The main data used is Landsat $8 \mathrm{OLI}$ recording of 2015. Processing and analysis of data in this study include, land cover classification, classification of vegetation index and analysis of overlay. Based on the analysis results, community forest area is about $28.351,4$ ha spread over 40 districts of Bogor. The largest community forest cover types is a type of agroforestry, and the smallest type of polyculture is the type of monoculture. Based on vegetation index, community forest with a high density is larger than community forest with low density.
\end{abstract}

Keywords: Spatial analysis, Cover types of community forest, Vegetation index, Bogor

\section{ABSTRAK}

Dalam rangka mendukung ketersediaan bahan baku kayu dan meningkatkan ekonomi masyarakat di Kabupaten Bogor, salah satu potensi yang dapat dikembangkan adalah hutan rakyat. Namun saat ini data dan informasi mengenai areal hutan rakyat belum terinventarisasi secara jelas. Data potensi areal hutan rakyat dapat diperoleh melalui pendekatan spasial menggunakan metode penginderaan jarak jauh dan sistem informasi geografi. Analisis spasial potensi hutan rakyat dilakukan untuk mengetahui sebaran, luas dan tipe tutupan hutan rakyat di Kabupaten Bogor. Data utama yang digunakan merupakan citra landsat 8 OLI perekaman tahun 2015. Pengolahan dan analisis data pada penelitian ini meliputi, klasifikasi tutupan lahan, klasifikasi indeks vegetasi dan overlay analisis. Berdasarkan hasil analisis diperoleh luas hutan rakyat sekitar 28.351,4 ha yang tersebar di 40 kecamatan Kabupaten Bogor. Tipe tutupan hutan rakyat terluas merupakan tipe agroforestri, diikuti tipe polikultur dan luas terkecil merupakan tipe monokultur. Berdasarkan indeks vegetasi, hutan rakyat dengan kerapatan tinggi lebih luas dibanding kerapatan rendah.

Kata kunci: Analisis spasial, Tipe tutupan hutan rakyat, indeks vegetasi, Kabupaten Bogor 


\section{PENDAHULUAN}

Kabupaten Bogor merupakan salah satu wilayah yang memiliki potensi hutan rakyat. Balai Pemantapan Kawasan Hutan (BPKH) Wilayah I Jawa - Madura bersama dengan Forest Governance and Multi stakeholder Forestry Programme-II (MFP -II) pada tahun 2008 melaporkan potensi hutan rakyat Kabupaten Bogor seluas 120.008,8 ha. Namun demikian di tahun yang sama, Dinas Pertanian dan Kehutanan Kabupaten Bogor juga melaporkan potensi hutan rakyat dengan luas yang jauh lebih kecil yaitu sekitar 16.354,8 ha. Terlepas dari pendekatan yang dilakukan, dengan perbedaan luas hutan rakyat tersebut menunjukkan bahwa belum sinerginya data dan belum terinventarisasi potensi hutan rakyat secara jelas di Kabupaten Bogor.

Inventarisasi dan pengukuran lapangan terhadap kondisi dan keberadaan hutan rakyat belum menjadi prioritas bagi pembangunan hutan seperti pada hutan negara. Namun seiring dengan berkembangnya paradigma baru dalam kebijakan pembangunan kehutanan yang berorientasi pada ekonomi kerakyatan, maka pengembangan hutan rakyat memiliki lebih banyak peluang. Peningkatan permintaan kayu menjadi peluang untuk pengembangan potensi kayu dari hutan rakyat.

Hutan rakyat di Indonesia mempunyai potensi besar, baik dari segi populasi pohon maupun jumlah rumah tangga yang mengusahakannya. Tercatat pada tahun 1999, kawasan hutan rakyat mampu memproduksi kayu mencapai $895.000 \mathrm{~m}^{3}$ dan mensuplai hingga $11 \%$ dari total kebutuhan kayu di pulau Jawa. Rata-rata produksi pada areal hutan rakyat mencapai $2,29 \mathrm{~m}^{3} / \mathrm{ha} /$ tahun, nilai tersebut 3 kali lebih besar dari rata-rata produksi tahunan pada areal-areal yang dikelola oleh pemerintah. Petani di Indonesia umumnya membudidayakan pohon secara intercropping dengan tanaman musiman untuk keperluan konsumsi sehari-hari maupun dijual untuk memperolah uang tunai (ESSC 2006).

Pulau Jawa memiliki rata-rata luas lahan hutan rakyat dalam satu hamparan sempit kurang dari 1 ha (Suharjito 2000 dan Haeruman et al., 1991). Walaupun hutan rakyat mempunyai potensi dan peranan yang cukup besar, akan tetapi pada umumnya di Jawa hanya sedikit hutan rakyat yang memenuhi luasan minimal sesuai dengan definisi hutan $(0,25 \mathrm{ha})$. Hal tersebut disebabkan rata-rata pemilikan lahan di Jawa yang sangat sempit, sehingga mendorong munculnya usaha pemanfaatan ruang seoptimal mungkin oleh pemilik lahan dengan cara membudidayakan tanaman-tanaman yang dapat dikonsumsi sehari-hari, serta tanaman-tanaman bernilai tinggi dengan daur yang pendek (Hardjanto 2000). Sangat berbeda dengan kondisi di luar Indonesia seperti negara-negara Eropa Utara (Filandia, Swedia, dan Norwegia), dimana luasan lahan kepemilikan berkisar antara 5-40 ha per keluarga (Harrison et al., 2002). Pengelolaan hutan rakyat dilakukan oleh masyarakat secara individual (pada tingkat keluarga) pada lahan miliknya, yang menyebabkan hutan rakyat tidak mengelompok pada suatu areal tertentu tetapi tersebar berdasarkan letak, luas pemilikan lahan dan keragaman pola usaha tani yang akan berpengaruh terhadap jumlah pohon pada setiap kepemilikan (Mindawati 2006).

Berbagai penelitian tentang hutan rakyat khususnya di Kabupaten Bogor telah banyak dilakukan tetapi belum menyediakan data dan informasi mengenai sebaran lokasi dan luas potensi hutan rakyat secara lengkap. Guna mendukung pengelolaan dan pengembangan hutan rakyat diperlukan ketersediaan data yang aktual mengenai besarnya potensi areal untuk pengembangan hutan rakyat. Inventarisasi hutan rakyat di Kabupaten Bogor dapat dilakukan melalui pendekatan geospasial menggunakan metode penginderaan jarak jauh dan analisis spasial. Sehingga diharapkan mampu mendapatkan data aktual yang dapat digunakan sebagai acuan bagi pengembangan hutan rakyat di Kabupaten Bogor. Penelitian ini bertujuan untuk menganalisis potensi hutan rakyat meliputi sebaran, luas, dan tipe tutupan hutan rakyat di Kabupaten Bogor. 


\section{METODE}

Waktu dan Lokasi

Penelitian ini dilaksanakan di seluruh wilayah Kabupaten Bogor yang secara geografis terletak antara $6^{\circ} 19^{\prime}-6^{\circ} 47^{\prime}$ lintang selatan (LS) dan $106^{\circ} 1^{\prime}-107^{\circ} 103^{\prime}$ bujur timur (BT), dengan luas sekitar $266.383 \mathrm{Ha}$. Kabupaten Bogor memiliki 40 kecamatan, 413 desa dan 17 kelurahan (430 desa/kelurahan). Penelitian dilakukan selama tiga bulan mulai dari April hingga Juni 2016. Pengolahan citra dan analisis data spasial dilakukan di Laboratorium Remote Sensing dan GIS, Departemen Manajemen Hutan, Fakultas Kehutanan, Institut Pertanian Bogor.

Jenis Data dan Peralatan

Data utama yang digunakan dalam penelitian ini merupakan data Citra Landsat 8 OLI yang diperoleh dari Earthexploler.usgs.gov. Citra landsat 8 yang digunakan merupakan perekaman tanggal 31 agustus 2015 path 122 dan row 65. Peta tematik (vektor) yang digunakan dalam penelitian ini meliputi peta topografi, sebaran sungai, jaringan jalan, titik tinggi, elevasi, pegunungan/bukit, desa/kelurahan, batas administrasi wilayah dan batas kawasan hutan kabupaten bogor. Pengolahan citra dan analisis spasial dilakukan menggunakan seperangkat komputer dilengkapi software ERDAS imagine 9.1 dan Arc GIS 9.3. Peralatan survei yang digunakan dalam penelitian ini adalah Global Positioning System (GPS), kamera digital, tally sheet lapang dan alat tulis.

\section{Pengolahan dan Analisis Data}

Citra Satelit Landsat 8 OLI di klasifikasi untuk mendapatkan informasi tutupan lahan menggunakan band kombinasi 6-5-4. Data citra Landsat 8 juga digunakan untuk mendapatkan informasi nilai kerapatan vegetasi berdasarkan band 5 dan 4 . Tahapan kegiatan ini meliputi kegiatan sebagai berikut :

1. Pengolahan awal (koreksi atmosfer, koreksi radiometri, dan koreksi geometri) Landsat 8 OLI tahun 2015.

2. Penajaman citra dan colour balancing

3. Penentuan tutupan lahan dari citra Landsat 8 OLI tahun 2015

4. Secara umum, klasifikasi menggunakan klasifikasi terbimbing (suvervised classification) mengacu pada klasifikasi 23 kelas tutupan lahan berdasarkan petunjuk teknis Dirjen Planologi Kehutanan. Klasifikasi lahan yang termasuk kategori hutan rakyat adalah hutan sekunder, hutan tanaman, perkebunan, hutan tanaman, pertanian lahan kering, pertanian lahan kering campur semak.

5. Perhitungan indeks vegetasi Landsat 8 OLI tahun 2015

6. Indeks vegetasi, seperti Normalized Difference Vegetation Index (NDVI), adalah salah satu produk data penginderaan jauh yang umum dalam menganalisa kondisi vegetasi. NDVI Nilai digunakan untuk mengidentifikasi kerapatan tanaman Nilai NDVI mempunyai rentang anatara -1 (minus) hingga 1 (positif). Nilai yang mewakili vegetasi berada pada rentang 0.1 hingga 0,7 , jika nilai NDVI di atas nilai ini menunjukkan tingkat kesehatan dari tutupan vegetasi yang lebih baik. Selanjutnya data raster hasil pengolahan indeks vegetasi kemudian dilakukan vektorisasi dengan mengubah format data dari img menjadi shp.

7. Overlay data indeks vegetasi terpilih dengan data tutupan lahan. Overlay dilakukan pada data penutupan lahan dan data hasil transformasi indeks vegetasi.

8. Perhitunngan luas dan sebaran hutan rakyat di 40 kecamatan di Kabupaten Bogor.

9. Perhitungan proporsi tipe tutupan dan kerapatan hutan rakyat di Kabupaten Bogor. 


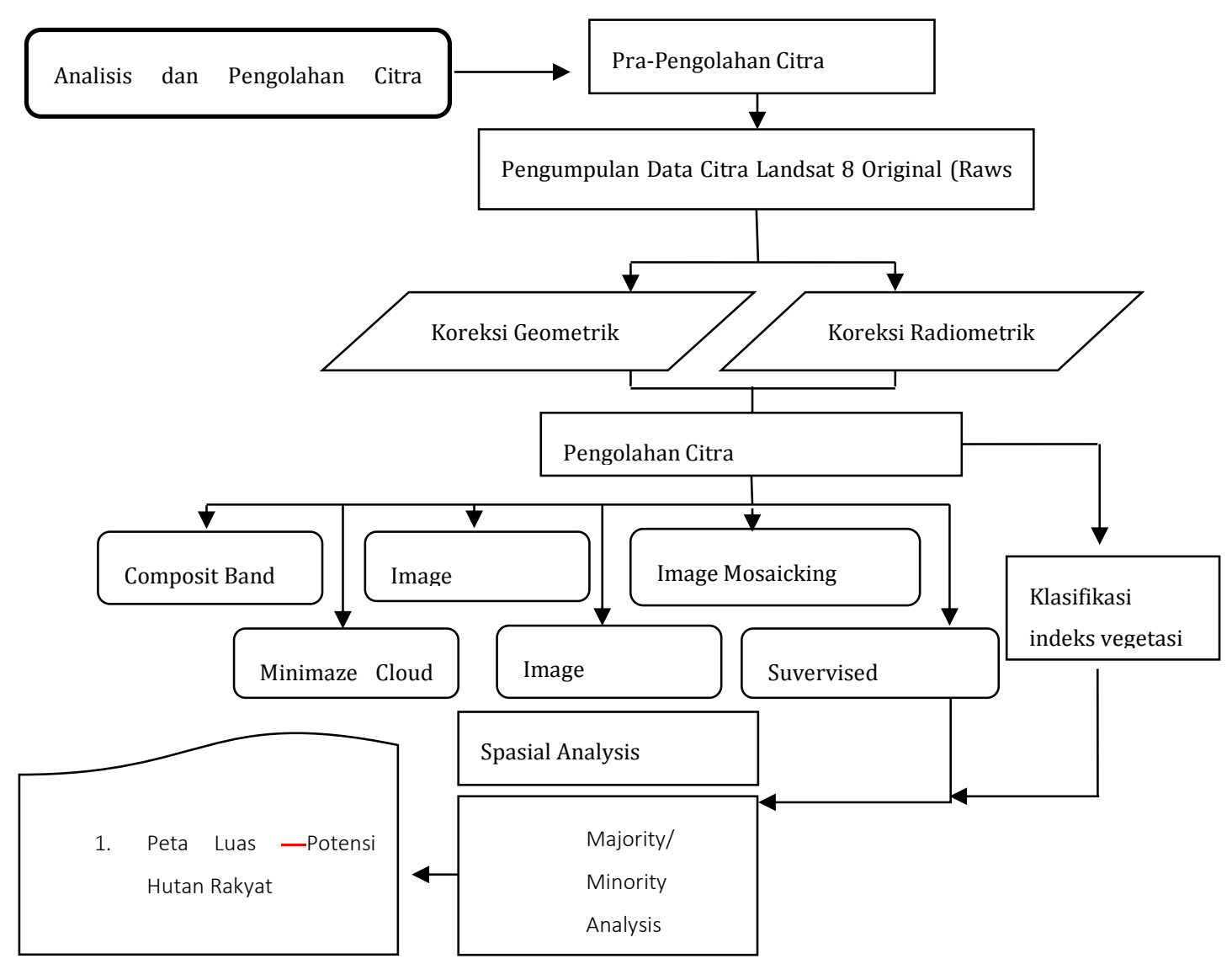

Gambar 1. Diagram alir pengolahan dan analisis data Figure 1. Flow chart of data processing and analysis

\section{HASIL DAN PEMBAHASAN}

\section{Luas Potensi Hutan Rakyat}

Analisis spasial potensi hutan rakyat di Kabupaten Bogor dilakukan dengan mengkombinasikan hasil interpretasi tutupan lahan dengan transformasi indeks vegetasi menggunakan data citra satelit landsat 8. Berdasarkan analisis yang telah dilakukan diperoleh luas total wilayah yang berpotensi dikembangkan untuk hutan rakyat adalah seluas $28.351,4$ ha. Potensi hutan rakyat tersebut tersebar di sembilan Sub DAS yang secara administratif berada pada 40 kecamatan di Kabupaten Bogor. 


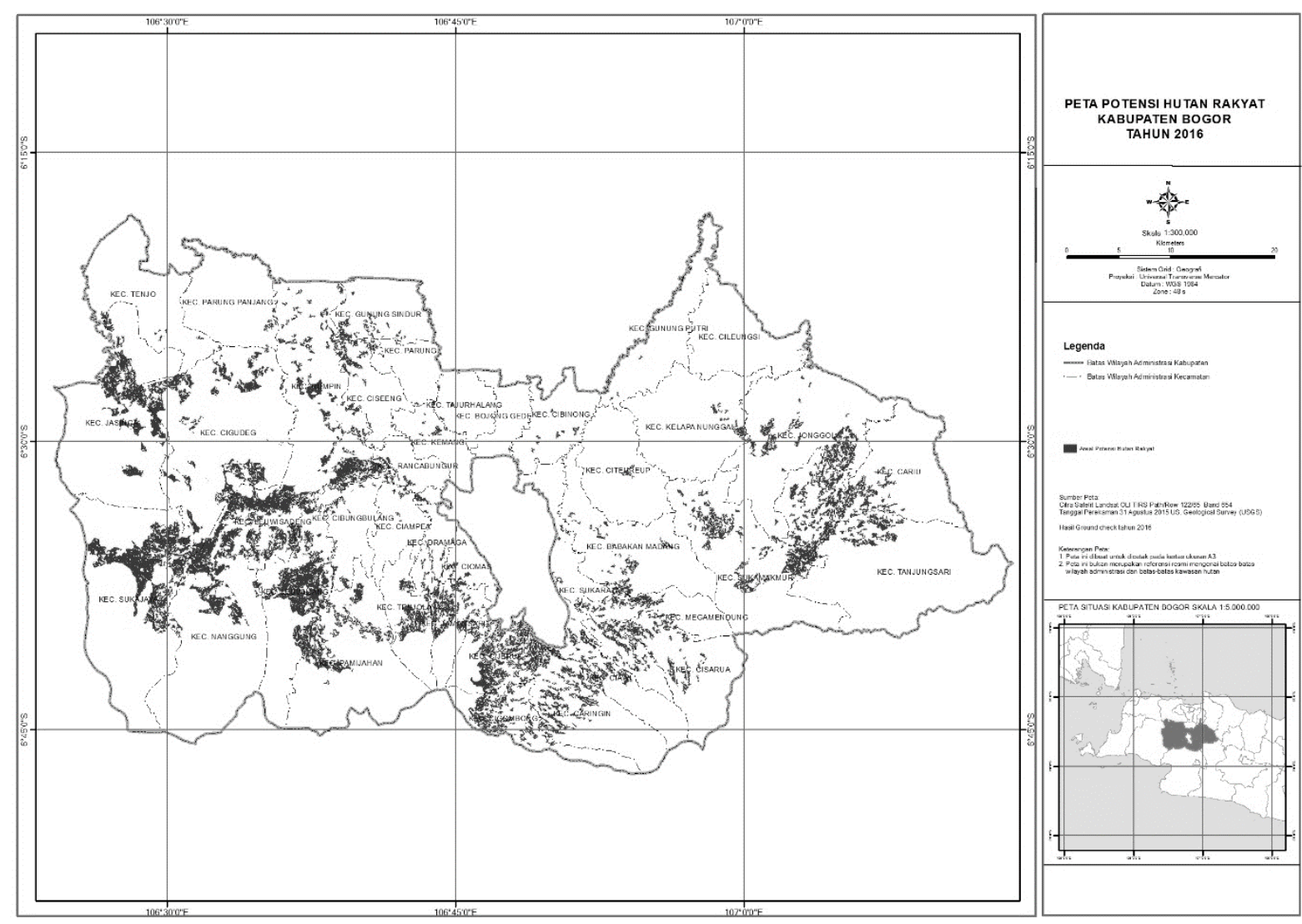

Gambar 2. Peta areal potensi hutan rakyat di 40 kecamatan Kabupaten Bogor Figure 2. Map of potential community forest areas in 40 sub-districts of Bogor Regency

Melalui informasi sebaran dan luas hutan rakyat di masing-masing sub DAS, prioritas pengembangan hutan rakyat bisa dilakukan dengan mempertimbangkan fungsi lansekap hutan dan keterkaitan antar bioekoregion. Luas potensi hutan rakyat berdasarkan sub DAS di Kabupaten Bogor disajikan pada Tabel 1.

Tabel 1. Luas potensi hutan rakyat berdasarkan Sub DAS di Kabupaten Bogor

Table 1. The potential area of community forest based on sub-watersheds in Bogor

\begin{tabular}{lll} 
& & Regency \\
\hline No. & Sub Das & Luas $(\mathrm{Ha})$ \\
\hline 1 & Cisadane & $14.921,2$ \\
3 & Cidurian & $3.895,7$ \\
3 & Citarum & $3.069,1$ \\
4 & Kali Bekasi & $2.072,4$ \\
5 & Ciujung & $1.549,0$ \\
6 & Ciliwung & $1.497,2$ \\
7 & Cimanceuri & $1.253,5$ \\
8 & Kali Angke & 67,7 \\
9 & Cimandiri & 25,5 \\
\hline Total & & $28,351.4$ \\
\hline
\end{tabular}

Luas areal hutan rakyat dengan persentase lebih dari $40 \%$ terdapat di tiga kecamatan yaitu Kecamatan leuwisadeng (43\%), Cijeruk (41\%) dan Sukajaya (40\%). 
Kecamatan Leuwiliang dan Tamansari masing-masing dengan persentase $32 \%$ dan $31 \%$ serta Kecamatan Sukamakmur, Caringin, Cigombong dan Nanggung memiliki presentase 20-32\%. Kemudian Kecamatan Megamendung, Tenjolaya, Ciawi, Cigudeg, Pamijahan, Rumpin, Jasinga dan Cisarua dengan presentase 10-19\%. Sementara 23 kecamatan lainnya memiliki presentase di bawah $10 \%$. Perbandingan luas potensi hutan rakyat di Kabupaten Bogor disajikan pada Gambar 2 dan persentase luas hutan rakyat terhadap luas wilayah kecamatan (di luar kawasan hutan) disajikan pada Gambar 3 dan Gambar 4.

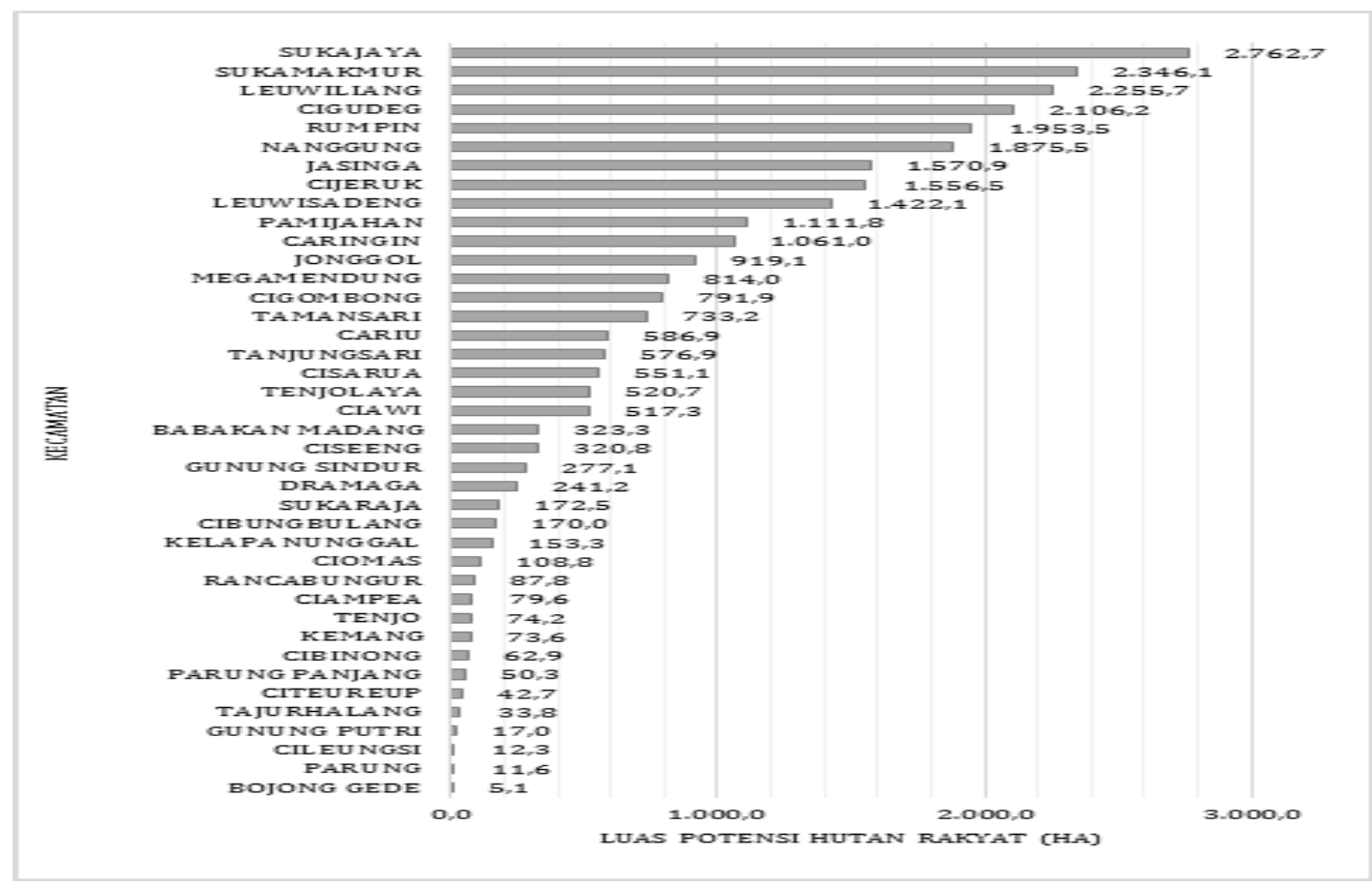

Gambar 3. Luas potensi hutan rakyat di 40 kecamatan Kabupaten Bogor Figure 3. The potential area of community forests in 40 sub-districts of Bogor Regency

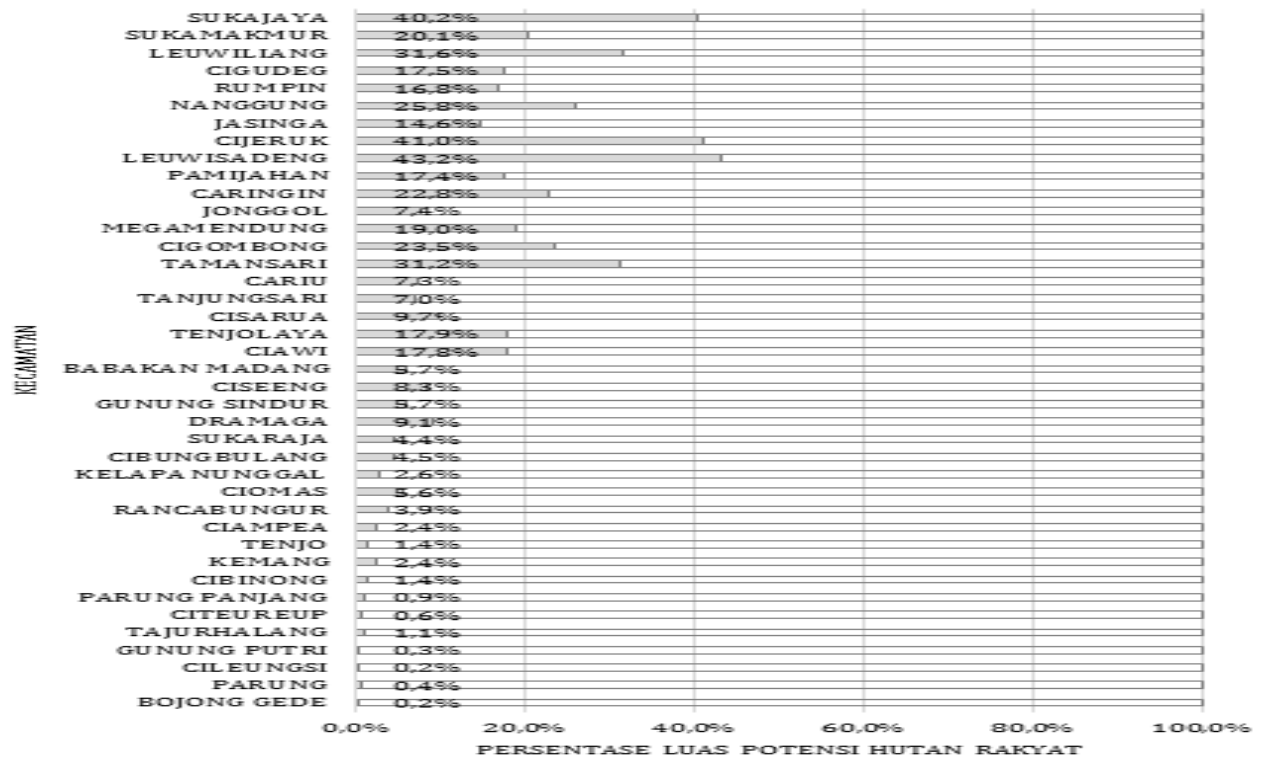

Gambar 4. Persentase luas hutan rakyat terhadap luas wilayah kabupaten bogor.

Figure 4. Percentage of community forest area to the area of Bogor Regency 


\section{Tipe Tutupan Hutan Rakyat}

Analisis tipe tutupan lahan hutan rakyat dilakukan melalui pendekatan visual (interpretasi citra satelit) dan survei lapangan. Hutan rakyat diidentifikasi melalui pengelompokkan objek yang homogen dalam suatu kelas tutupan lahan yang dilakukan secara manual berdasarkan elemen penafsiran dan titik koordinat yang diperoleh dilapangan. Elemen yang diperhatikan adalah warna, ukuran, bentuk, pola, tekstur, bayangan asosiasi dan lokasi dilapangan. Tutupan hutan rakyat dibagi menjadi tiga tipe yaitu hutan rakyat murni (monoculture), hutan rakyat campuran (polyculture) dan wana tani (agroforestry). Hutan rakyat murni yaitu hutan rakyat yang hanya terdiri dari satu jenis tanaman pokok berkayu yang ditanam secara homogen secara monokultur. Hutan rakyat campuran yaitu hutan rakyat yang terdiri dari jenis pohon-pohonan yang ditanam secara campuran. Sementara, hutan rakyat wana tani yaitu yang mempunyai bentuk usaha kombinasi antara kehutanan dan cabang usaha tani lainnya seperti tanaman pangan, perkebunan, peternakan, perikanan dll yang dikembangkan secara terpadu.

Hasil identifikasi visual terhadap tutupan hutan rakyat antaralain (1) hutan rakyat campuran memiliki tekstur yang relatif kasar dengan warna hijau muda agak gelap; (2) Hutan rakyat agroforestri memiliki tekstur yang halus dengan campuran warna hutan dan tanaman pertanian biasanya terdapat antara pemukiman dan sawah; (3) Hutan rakyat monokultur memiliki kemiripan dengan hutan rakyat agroforestri yaitu relatif halus dengan warna hijau muda yang agak lembut. Identifikasi hutan rakyat juga dilakukan dengan melihat hubungan indeks vegetasi dengan tipe tutupan hutan rakyat dan mengetahui kerapatan tegakan. Rentang $0-1$ diklasifikasi perpixel untuk mendapatkan kelas tutupan hutan rakyat. Tutupan hutan rakyat di Kabupaten Bogor teridentifikasi dengan nilai NDVI (Normalize Difference Vegetation Index) antara 0,32-0,6. Analisis tipe tutupan lahan selain menggunakan pendekatan visual juga dilakukan survei lapangan (ground check), untuk menilai dan membandingkan hasil pengkelasan citra dengan kondisi faktual di lapangan (accurracy assessment).

Berdasarkan analisis spasial potensi hutan rakyat di Kabupaten Bogor, tipe tutupan hutan rakyat terluas adalah hutan rakyat agroforestri yaitu seluas $17.757,7$ ha atau sebesar $63 \%$ dari total hutan rakyat di Kabupaten Bogor. Sementara hutan rakyat polikultur memiliki luas dengan persentase sebesar $34 \%(9.622,2$ ha) dan hutan rakyat monokultur dengan persentase terkecil yaitu $3 \%(971,4 \mathrm{ha})$. Pada prakteknya sangat sulit membedakan dan memisahkan kelas hutan rakyat monokultur secara digital. Hal ini dipengaruhi oleh luas hutan rakyat monokulur yang relatif kecil berada di dalam atau diantara hutan rakyat dengan tipe agroforestri atau polikultur. Sehingga besar kemungkinan tipe tutupan hutan rakyat monokultur terasosiasi dengan tipe tutupan hutan rakyat lainnya.

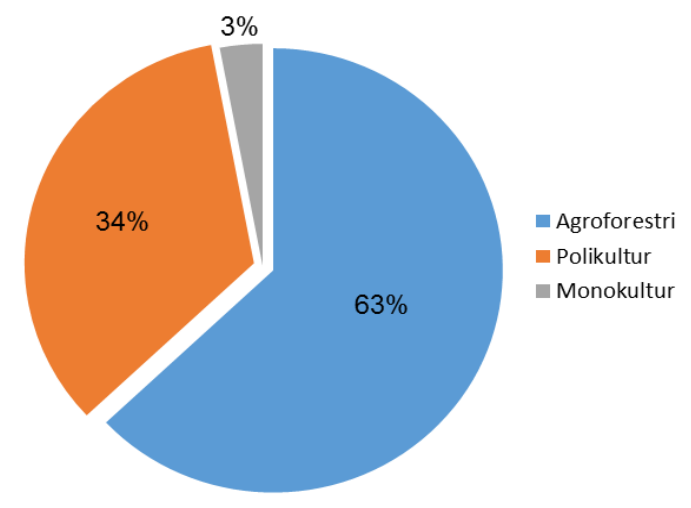

Gambar 5. Luas tipe tutupan hutan rakyat di Kabupaten Bogor

Figure 5. Extent of type of community forest cover in Bogor Regency 
Kerapatan Hutan Rakyat

Kerapatan hutan rakyat di Kabupaten Bogor terdiri dari kerapatan sedang dan tinggi, seperti dijelaskan pada Tabel 2 dibawah ini.

Tabel 2. Kelas kerapatan tipe hutan rakyat di Kabupaten Bogor

Table 2. Class density of community forest types in Bogor Regency

\begin{tabular}{llllll}
\hline Kerapatan & Agroforestri & Monokultur & Polikultur & Luas Total & NDVI \\
\hline Sedang & $9.883,9$ & 233,7 & - & $10.117,6$ & $0,32-0,52$ \\
Tinggi & $7.873,8$ & 737,7 & $9.622,2$ & $18.233,8$ & $0,52-0,6$ \\
\hline Luas Total & $17.757,7$ & 971,4 & $9.622,2$ & $28.351,4$ & \\
\hline
\end{tabular}

Tabel 2 menunjukkan hubungan antara struktur tegakan dengan kerapatan hutan rakyat. Hutan rakyat polikultur seluruhnya termasuk dalam kerapatan tinggi. Hal ini sesuai dengan hasil pengecekan lapangan dimana struktur tegakan hutan rakyat polikultur berupa kayu-kayuan campuran baik yang ditanam maupun yang tumbuh secara alami memiliki kerapatan yang tinggi tanpa adanya tanaman pertanian lain. Sementara Hutan rakyat agroforestri dan monokultur memiliki kerapatan dari sedang hingga tinggi.

Agroforestri dengan kerapatan sedang teridentifikasi lebih luas dari pada kerapatan tinggi. $\mathrm{Hal}$ ini dipengaruhi oleh struktur tegakan dan kerapatan vegetasi yang membentuk agroforestri. Hutan rakyat agroforestri dengan kerapatan tinggi mengindikasikan lebih banyaknya tanaman kayu-kayuan dan kebun dengan tajuk yang rapat dalam suatu lahan. Sementara agroforestri dengan kerapatan sedang mengindikasikan bahwa hutan rakyat terasosiasi dengan tanaman pertanian lain yang relatif tidak terlalu rapat. Kerapan hutan rakyat monokulturi dipengaruhi oleh umur dan jenis tegakan. Hutan rakyat monokultur dengan kerapatan tinggi umumnya memiliki umur diatas lima tahun untuk jenis fast growing dan umur tegakan di bawah lima tahun mengindikasikan kerapatan sedang.

\section{KESIMPULAN}

Luas total wilayah yang berpotensi dikembangkan untuk hutan rakyat di Kabupaten Bogor adalah seluas $28.351,4$ ha. Potensi hutan rakyat tersebut tersebar di sembilan Sub DAS yang secara administratif berada pada 40 kecamatan di Kabupaten Bogor. Lebih dari setengah luas total hutan rakyat di Kabupaten Bogor berada di Sub DAS Cisadane yaitu sekitar 14.921,2 ha. Adapun secara administrasi kecamatan, terdapat empat kecamatan yang memiliki potensi hutan dengan luas lebih dari 2.000 ha, yaitu: Kecamatan Sukajaya (2.762,7 ha), Cigudeg (2.346,1 ha), Sukamakmur (2.255,7 ha), dan Leuwiliang (2.106,2 ha). Tipe tutupan hutan rakyat terluas adalah hutan rakyat agroforestri yaitu seluas 17. 757,7 ha $(63 \%)$, diikuti hutan rakyat polikultur seluas $9.622,2$ ha (34\%), dan hutan rakyat monokultur seluas 971,4 ha $(3 \%)$.

\section{DAFTAR PUSTAKA}

BPKH XI dan MFP-II. 2008. Profil Badan Pelaksana Penyuluhan Pertanian Perikanan dan Kehutanan Kabupaten Bogor 2009. Bogor: Balai Pemantapan Kawasan Hutan.

[ESSC] Environmental Science For Social Change. 2006. Small Scale Tree Farming In Asia: Java Case. Singapore: ESSC Inc 
Haeruman H, R Abidin, Hardjanto, E Suhendang. 1991. Studi Kemungkinan Pengembangan Konservasi Lahan melalui Hutan Rakyat. Fakultas Kehutanan IPB, Bogor.

Hardjanto. 2000. Beberapa Ciri Pengusahaan Hutan Rakyat di Jawa. Suhardjito D, editor. Bogor: Program Penelitian dan Pengembangan Kehutanan Masyarakat (P3KM).

Harrison S, J Herbohn, A Niskanen. 2002. Non Industrial, Smallholder, Small-scale and Family Forestry: What's in a Name? Small-scale Forest Economic,Management and Policy, 1(1): 1-11.

Mindawati NA, Widiarti, B Rustaman. 2006. Review Hasil Penelitian : Hutan Rakyat. Pusat Penelitian dan Pengembangan Hutan Tanaman, Badan Penelitian dan Pengembangan Kehutanan. Bogor.

Suharjito D. 2000. Hutan Rakyat di Jawa: Perannya dalam Perekonomian Desa. Program Penelitian dan Pengembangan Kehutanan Masyarakat Fakultas Kehutanan IPB, Bogor. 